\title{
PERENCANAAN LANSKAP PRODUKTIF UNTUK MODEL KAWASAN RUMAH PANGAN LESTARI DI PEDESAAN
}

\author{
A LANDSCAPE PRODUCTIVE PLANNING \\ FOR FOOD GARDEN HOUSE MODEL IN RURAL AREAS
}

\author{
Ane Novianty*, Ivan Sayid Nurahman, Tiktiek Kurniawati \\ Fakultas Pertanian, Universitas Galuh \\ *Email: Noviantyane29@gmail.com \\ (Diterima 06-08-2021; Disetujui 26-08-2021)
}

\begin{abstract}
ABSTRAK
Pengabdian dilakukan pada Kelompok Wanita Tani (KWT) Subur Tani Desa Banjarsari Kecamatan Sukaresik Kabupaten Tasikmalaya. Tujuan kegiatan ini untuk: 1) memberikan penyuluhan tentang model KRPL dengan vertikultur, dan 2) memberikan gambaran pemanfaatan pekarangan dengan pengembangan lanskap produktif. Kegiatan pengabdian ini diikuti oleh seluruh anggota KWT Subur Tani sebanyak 15 orang. Tim abdimas bertindak sebagai fasilitator penyuluhan dan pelaksanaan praktik perencanaan lanskap pekarangan vertikultur. Lanskap pekarangan yang dibuat mudah diaplikasikan dan dapat disesuaikan dengan ukuran lahan berapapun. Pekarangan yang luas atau sempit dapat digunakan secara optimal tanpa mengesampingkan syarat tumbuh tanaman itu sendiri. Hasil akhir dari kegiatan penyuluhan dan praktik perencanaan lanskap telah mampu mengubah cara pandang anggota KWT dalam mengusahakan pekarangan yang optimal.
\end{abstract}

Kata kunci: Kelompok wanita tani, KRPL, Perencanaan lanskap

\section{ABSTRACT}

Devotion was conducted on farmer women's group of Subur Tani in Banjarsari, Sukaresik, Tasikmalaya. The activity aims to: 1) providing an information about food garden house model with verticulture, and 2) providing an illustration about yard usage with development of landscape planning. This activity joined by members of Subur Tani's group about 25 person. Abdimas's team act as facilitator of counseling and practice to make a landscape vertivulture planning. A yard landscape made easily to optimally apply with no release the growing plants. The result of this counseling and landscape planning practice has been able to change a viewpoints of farmer women's member in yard optimalization.

Keywords: Farmer women's group, Food garden house, landscape planning

\section{PENDAHULUAN}

Kawasan Rumah Pangan Lestari (KRPL) merupakan salah satu program Kementerian Pertanian untuk mengoptimalkan lahan pekarangan yang ramah lingkungan dalam suatu kawasan (Badan Litbang Pertanian, 2021). Program KRPL merupakan upaya pemerintah bersama dengan Kementerian Pertanian untuk meningkatkan ketahanan pangan dan gizi keluarga (Putri et al, 2015). Program tersebut diharapkan dapat mewujudkan kemandirian pangan sehingga dapat membantu perekonomian keluarga.

Program KRPL identik dengan program sejenis yang disebut dengan program homegarden. Beberapa negara yang telah mempraktekan program ini diantaranya terdistribusi di bagian Afrika Timur dan Barat, Asia Selatan dan Tenggara, Kepulauan Pasifik dan Meso Amerika sebagai fenomena tropis (Mohri, 2013). Secara umum keberhasilan homegarden banyak dirasakan di beberapa negara yang mengusahakannya. 
Di Bangladesh misalnya, pemerintah dikatakan mampu meningkatkan ketahanan pangan dan mengurangi malnutrisi sekaligus mengurangi kemiskinan di kawasan pedesaan Bangladesh (Ferdous et al, 2016). Walaupun KRPL telah sukses diterapkan di beberapa negara, pada kenyataannya hanya sebagian kecil masyarakat di Indonesia yang merencanakan halaman rumah sebagai fungsi pangan atau menanam tanaman yang dapat memenuhi pangan keluarga (Siti dan Sarwadi, 2015). Hal ini menunjukkan bahwa masih banyak masyarakat yang tidak paham arti penting fungsi pekarangan yang baik yang dapat mendukung fungsi ekosistem dan fungsi lainnya.

Seperti yang terjadi pada KWT Subur Tani Desa Banjarsari Kecamatan Sukaresik Kabupaten Tasikmalaya. Lahan pekarangan yang luas tidak dimanfaatkan secara maksimal sesuai fungsinya. Budidaya tanaman di pekarangan pun dilakukan tanpa adanya perawatan yang baik. Berdasarkan pengamatan lapangan, pekarangan yang dimiliki anggota KWT Subur Tani masih digunakan sebatas untuk menanam tanaman tanpa perencanaan untuk penataan yang dapat memperindah tempat tinggal. Hal ini diduga karena anggota KWT tersebut kurang memperoleh pengetahuan tentang desain pekarangan dan pemanfaatan pekarangan secara optimal dalam pengembangan lanskap produktif.

Oleh karena permasalahan tersebut perlu dilakukan pemberdayaan yang dapat mengubah perilaku masyarakat menjadi lebih produktif dengan optimalisasi pekarangan. Tujuan kegiatan pengabdian masyarakat ini adalah 1) memberikan penyuluhan tentang model KRPL dengan vertikultur, dan 2) mendapat gambaran pemanfaatan pekarangan dengan pengembangan lanskap produktif.

\section{BAHAN DAN METODE}

\section{Waktu dan Lokasi}

Pelaksanaan pengabdian dilakukan di Desa Banjarsari Kecamatan Sukaresik Kabupaten Tasikmalaya pada bulan Januari - Februari 2021. Kelompok sasaran pengabdian yaitu anggota KWT Subur Tani yang berjumlah 15 orang.

\section{Metode Pelaksanaan}

Berdasarkan hasil analisis situasi dan kerangka permasalahan yang telah dipaparkan maka pelaksanaan kegiatan pengabdian ini dibagi menjadi beberapa tahapan, yaitu:

1. Tahap 1: Penyuluhan

Kegiatan pada tahap ini adalah pelaksanaan penyuluhan terkait materi pengenalan M-KRPL Vertikultur yang meliputi: tujuan dan manfaat ekonomis dalam optimalisasi 
pekarangan. Materi penyuluhan juga menjelaskan terkait penggunaan alat dan bahan yang mudah didapat sehingga memungkinkan untuk memperkecil biaya produksi.

2. Tahap 2: Perencanaan Lanskap Produktif

Kegiatan ini dilakukan dengan metode praktik pada salah satu lahan pekarangan anggota KWT. Output kegiatan pada tahap ini yaitu gambaran sederhana mengenai potensi pekarangan anggota KWT dari aspek luas, penggunaan ruang dan pemilihan vegetasi. Lanskap yang dibuat mudah diaplikasikan dan dapat disesuaikan pada berbagai ukuran lahan.

3. Tahap 3: Kegiatan Penanaman

Sesuai dengan perencanaan lanskap yang telah dibuat, tahapan ini merupakan realisasi dari tahap sebelumnya. Model vertikultur, jumlah populasi tanaman per satuan luas, komoditas yang dibudidayakan, serta media tanam yang digunakan disesuaikan dengan perencanaan lanskap.

Metode yang digunakan pada pelaksanaan pengabdian yaitu metode FGD (Focus Group Discussion) dan praktik langsung. Metode FGD dan praktik diikuti oleh pada anggota KWT Subur Tani sebagai peserta. Tagihan pada para peserta dari hasil FGD dan praktik pembuatan lanskap berupa implementasi KRPL kaitannya dengan optimalisasi pekarangan produktif.

\section{HASIL DAN PEMBAHASAN}

Mitra kegiatan pengabdian ini adalah KWT Subur Tani yang berlokasi di Desa Banjarsari Kecamatan Sukaresik Kabupaten Tasikmalaya. Walaupun masih dalam kondisi pandemi Covid-19, pengabdian dilaksanakan secara langsung (tatap muka) mengingat kondisi jaringan wilayah perdesaan dan keterbatasan mitra dalam mengakses internet.

\section{Proses Pelaksanaan Pengabdian}

\section{Tahap I: Penyuluhan}

Sennet dan Cabb dalam Suharto (2005) menyatakan bahwa, ketidakberdayaan masyarakat disebabkan oleh beberapa faktor seperti ketiadaan jaminan ekonomi, ketiadaan pengalaman dalam arena politik, ketiadaan akses terhadap informasi, ketiadaan dukungan finansial, ketiadaan pelatihan dan adanya ketegangan fisik maupun emosional. Memperhatikan kondisi tersebut untuk seseorang menjadi berdaya diantaranya memerlukan akses terhadap finansial dan informasi yang mendukung untuk dapat bangkit dan berperan dalam kegiatan pembangunan. Stich dan Eagle dalam Purwanto (2015) 
mengungkapkan pentingnya keterlibatan masyarakat dalam proses implementasi yang seharusnya dipahami lebih dari sekedar adanya kebutuhan.

Kegiatan penyuluhan dimaksudkan untuk memberikan gambaran dan motivasi yang mendorong partisipasi aktif dari anggota KWT. Materi yang disampaikan salah satunya perumusan tujuan dari pengusahaan KRPL pada KWT Subur Tani.

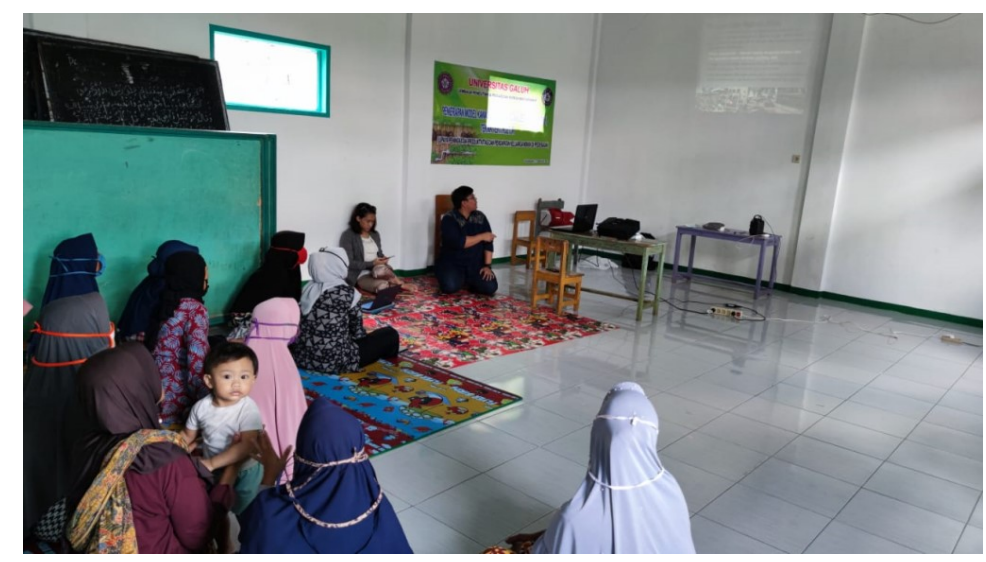

Gambar 1. Pemaparan Materi Penyuluhan

Pada kegiatan ini juga dilakukan pemutaran video singkat mengenai contoh-contoh model KRPL yang mudah dilakukan dan dengan tujuan pengusahaannya sehingga para peserta dapat membandingkan model mana yang paling cocok untuk diaplikasikan di lingkungannya. Antusiasme peserta terlihat dari banyaknya pertanyaan-pertanyaan terkait model KRPL yang baru diketahui oleh para peserta. Hasil dari kegiatan ini adalah rumusan tujuan pengusahaan KRPL pada KWT Subur Tani diantaranya:

a. Pemenuhan Pangan Keluarga

Produktifitas yang dihasilkan tiap rumah tangga salah satunya ditentukan oleh luas pekarangan yang dimiliki. Walaupun demikian pemenuhan pangan keluarga dalam lahan sempit masih dapat dilakukan dengan cara diversifikasi. Pemenuhan kebutuhan pangan keluarga dalam pengertian ini adalah jika suatu pengusahaan KRPL mampu berkontribusi dalam menyuplai kebutuhan pangan keluarga sehingga dapat meminimalisir biaya belanja kebutuhan pangan

b. Peningkatan Pendapatan Keluarga

Peningkatan pendapatan keluarga ini dapat dicapai ketika pengusahaan KRPL mampu menghasilkan produk melebihi kebutuhan pangan keluarganya. Sisa hasil produksi diperuntukan dalam penjualan produk yang diharapkan dapat memperoleh keuntungan dari hasil penjualan. Kegiatan penjualan produk dapat dilakukan individu maupun dikolektif oleh KWT. 


\section{Tahap 2: Perencanaan Lanskap Pekarangan}

Tipe rumah dan pekarangan (luas dan bentuk) menyebabkan perbedaan tangkapan (interupsi) sinar matahari masuk. Tangkapan sinar matahari di pekarangan merupakan aspek penting untuk kelangsungan pemberdayaan pekarangan, karena proses fotosintesa tanaman memerlukan energi matahari untuk membuat makanan dan melangsungkan hidupnya. Perencanaan lanskap pekarangan dilakukan dengan metode praktik langsung pada salah satu rumah anggota KWT Subur Tani. Beberapa aspek yang ditinjau dalam perencanaan lanskap diantaranya aspek luas, penggunaan ruang dan pemilihan vegetasi.

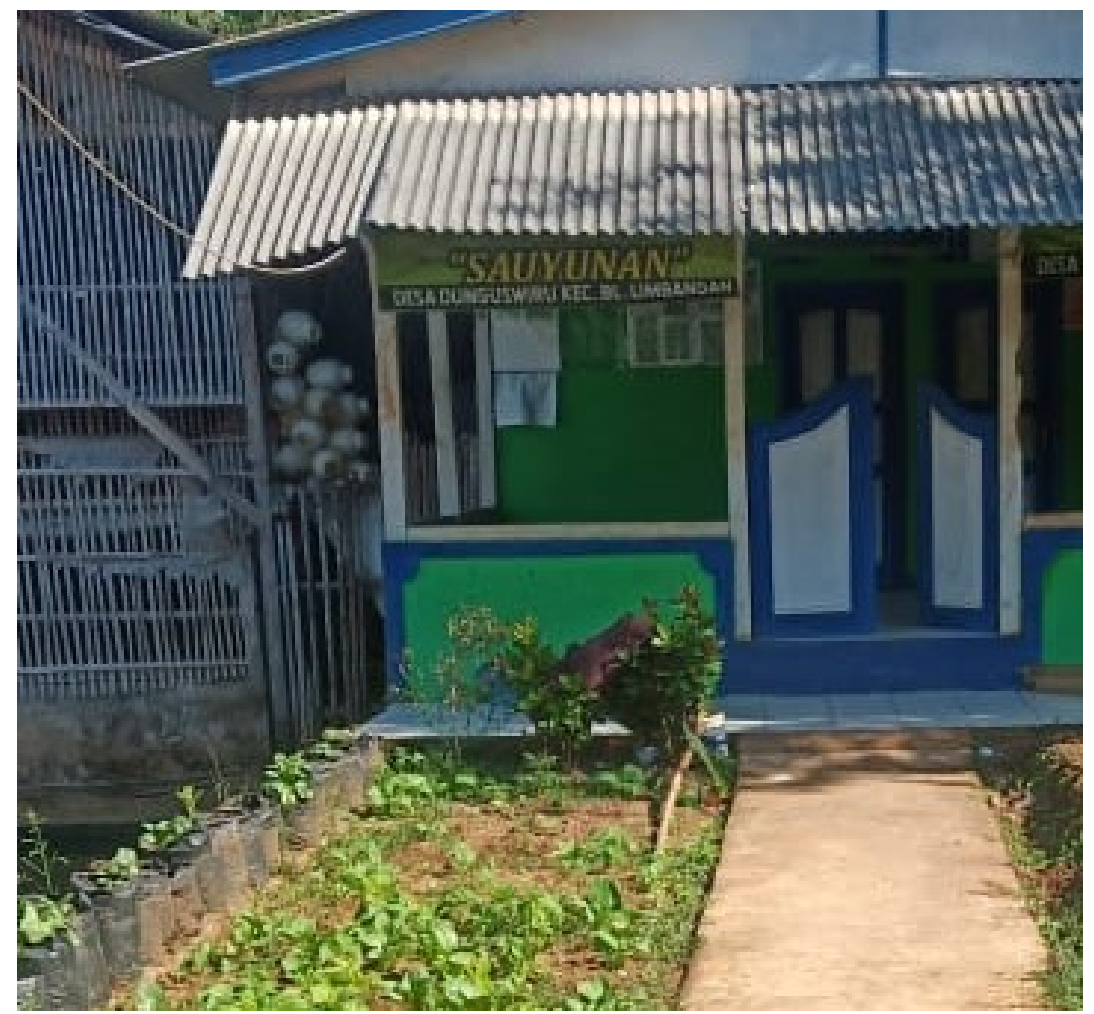

\section{Gambar 2. Tampilan Pekarangan Rumah Anggota KWT Sebelum Digunakan Praktik}

Seperti yang tampak pada Gambar 2, pekarangan salah satu rumah anggota KWT sama sekali belum memenuhi syarat lanskap produktif. Terlihat dari pengunaan lahan yang luas namun tidak optimal sehingga masih banyak space yang terbuang dan kemudian bercampur dengan tumbuhan liar. Jika dilakukan diversifikasi dengan teknik vertikultur, jumlah pohon yang dapat ditanam akan lebih banyak. Vertikultur dapat diartikan sebagai teknik budidaya tanaman secara vertikal sehingga penanaman dilakukan secara bertingkat. Pemanfaatan teknik vertikultur ini memungkinkan untuk berkebun dengan memanfaatkan tempat secara efisien (Ati dan Solikhah, 2015). Penanaman vertikultur yang optimal memungkinkan untuk mendapatkan produktifitas hasil yang lebih tinggi. 


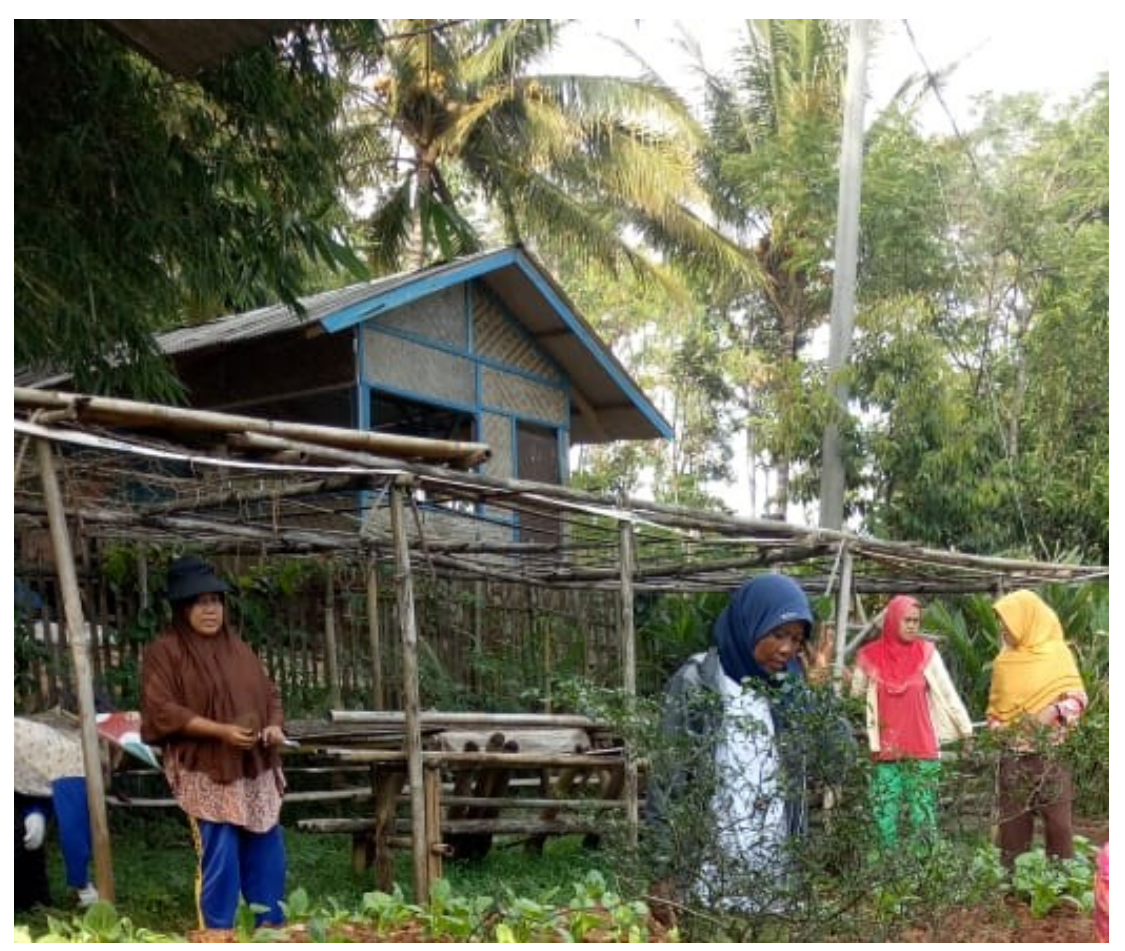

\section{Gambar 3. Praktik Pengukuran Lahan dan Penghitungan Jumlah Tanaman Per Meter Persegi}

Pada tahap ini, mitra belajar secara langsung bagaimana cara mengukur panjang, lebar, dan tinggi dari lahan yang akan digunakan. Pekarangan yang terhampar luas tentunya akan memiliki karakteristik dan model penggunaan rak yang berbeda dengan pekarangan lahan sempit. Namun praktik perencanaan lanskap ini dilakukan lebih sederhana sehingga mitra dapat mengaplikasikan dengan mudah pada lahan jenis apapun dan dengan luas yang berbeda sekalipun. Output yang dihasilkan pada tahap ini diantaranya optimalisasi penggunaan ruang per meter persegi dan tumpangsari serta rencana rotasi komoditas per meter persegi. Jika mitra memiliki lahan lebih luas dari 1 meter persegi, perencanaan lanskap ini dapat disesuaikan dengan mudah dengan cara mengkalikan standar penggunaan ruang per meter persegi dengan luas lahan yang dimiliki.

3. Tahap 3: Realisasi KRPL berdasarkan hasil Penyuluhan dan Praktik

Pada tahap ini, masing-masing anggota KWT merealisasikan sendiri konsep KRPL yang telah dituangkan dalam perencanaan lanskap. Kegiatan ini dilakukan secara mandiri oleh mitra yang telah berbekal pengetahuan dari penyuluhan dan praktik perencanaan lanskap. Monitoring dilakukan untuk mengontrol jalannya kegiatan KRPL apakah dilakukan atau tidak dan sesuai perencanaan lanskap atau tidak. 


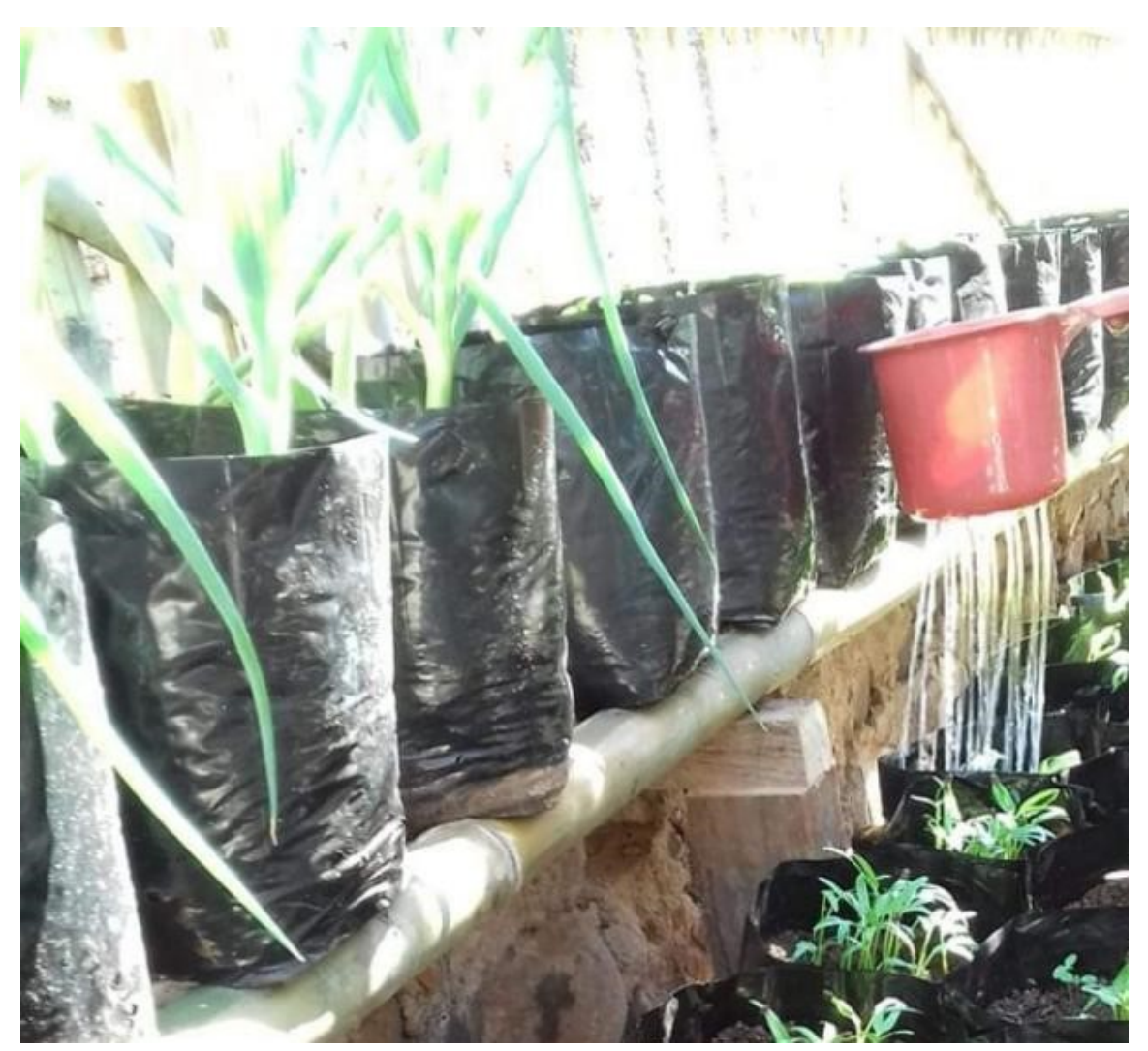

Gambar 4. Vertikultur dengan Lanskap Produktif

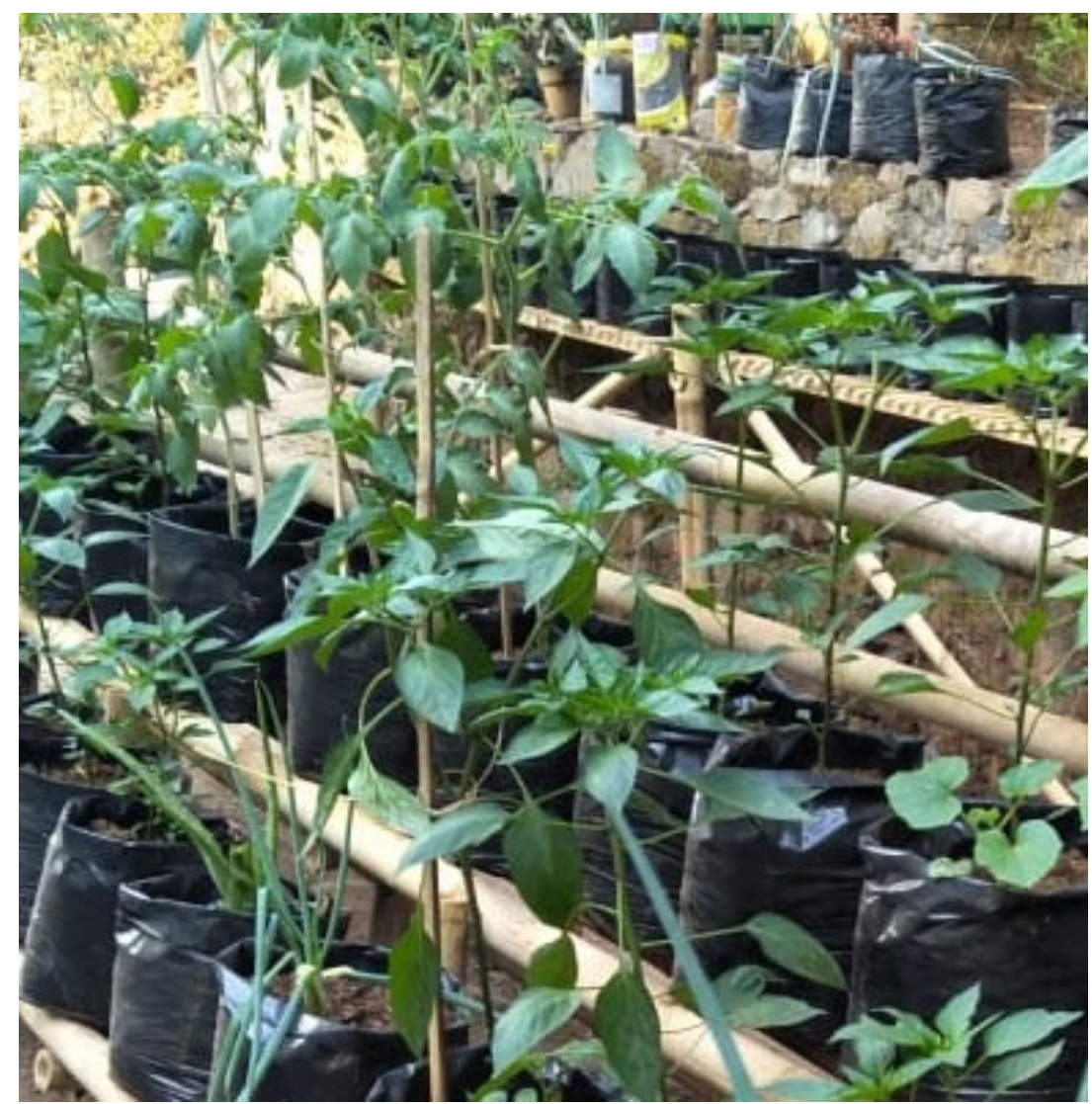

Gambar 5 . Diversifikasi dalam Satu Rak 
Gambar 4 dan 5 menunjukkan realisasi dari hasil kegiatan penyuluhan dan praktik perencanaan lanskap. Terlihat bahwa setiap pekarangan memiliki jenis rak dan komoditas yang berbeda. KRPL vertikultur yang digunakan telah memenuhi syarat tumbuh tanaman, diversifikasi, dan optimalisasi.

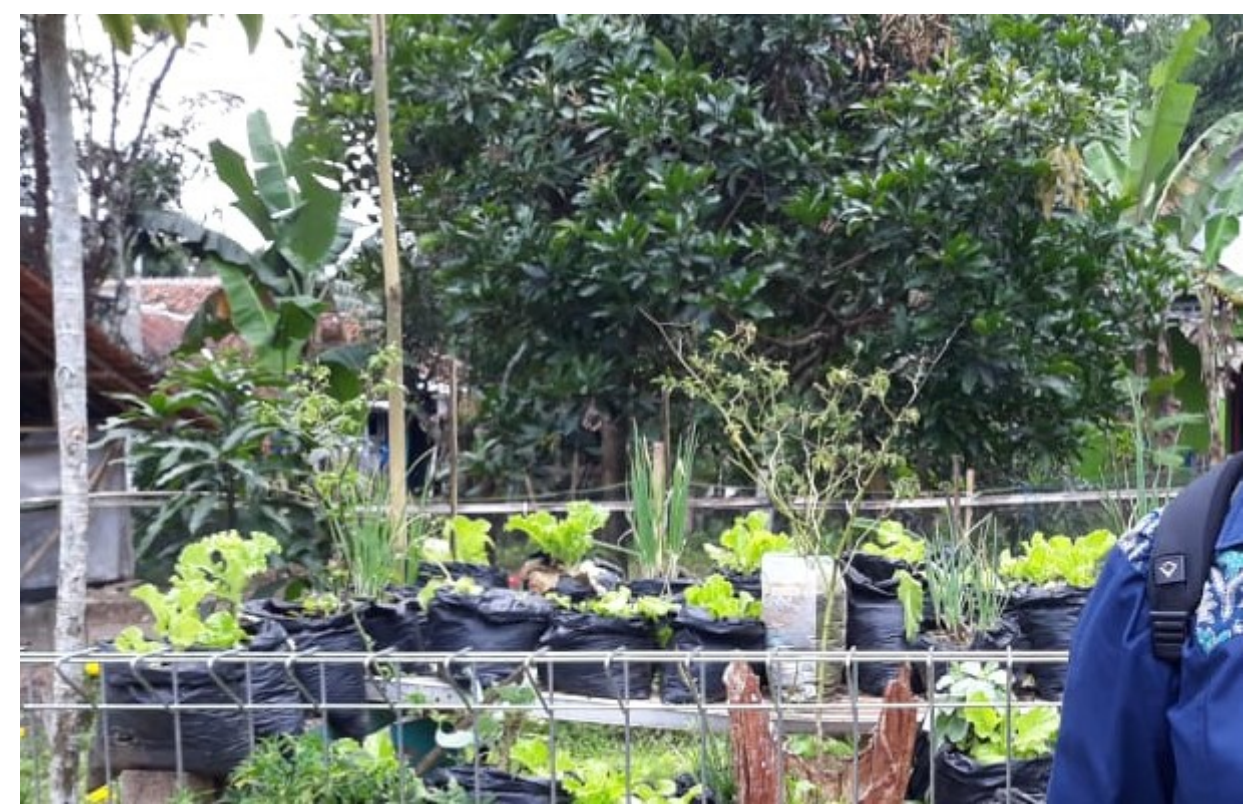

Gambar 6. Kegiatan Monitoring

Berdasarkan monitoring yang dilakukan dengan peninjauan langsung ke masingmasing rumah anggota KWT, dapat disimpulkan bahwa penyuluhan dan praktik perencanaan lanskap telah mampu menambah pengetahuan mitra terkait model KRPL dan mampu mengubah cara pandang yang baru terkait pengusahaan pekarangan. Vertikultur yang didesain juga telah memunculkan nilai estetika lingkungan, selain mengikuti kaidah syarat pertumbuhan tanaman yaitu mendapatkan sinar matahari dan air yang cukup. Sesuai dengan pernyataan Mohamad dan Mirajuddin (2013), bahwa persyaratan aplikasi teknologi vertikultur yang harus dipenuhi dalam budidaya di lahan pekarangan yang sempit adalah harus memiliki nilai estetika atau keindahan, sehingga selain dapat menghasilkan tanaman sehat dan bergizi untuk dikonsumsi, juga dapat memperindah halaman rumah.

\section{KESIMPULAN}

Berdasarkan kegiatan yang telah dilaksanakan maka diperoleh kesimpulan sebagai berikut:

1. Penyuluhan yang dilakukan telah mampu memberikan pengetahuan dan cara pandang baru bagi mitra dalam melaksanakan KRPL. 
2. Perencanaan lanskap telah mampu mitra dalam mendesain pekarangan produktif secara optimal dengan vertikultur yang efektif dan diversifikasi.

\section{DAFTAR PUSTAKA}

Ati, K dan Solikhah, U. 2015. Peningkatan Pendapatan Keluarga Melalui Pemanfaatan Pekarangan Rumah dengan Menggunakan Teknik Vertikultur. Jurnal Inovasi dan Kewirausahaan, 4(2):94-101.

Badan Litbang Pertanian. 2012. Pedoman Umum Model Kawasan Rumah Pangan Lestari. Jakarta: Badan Penelitian dan Pengembangan Pertanian.

Ferdous, Z. 2016. Development of Home Garden Model for Year Round Production and Consumption for Improving Resource-poor Household Food Security in Bangladesh. Wagening Journal of Life Sciences, 78: 103:110.

Mohamad, H dan Mirajuddin, M. 2013. Pendampingan Pembuatan Media Vertikultur untuk Penanaman Tumbuhan Obat dalam Pemaksimalan Pekarangan Rumah. Jurnal Inovasi dan Kewirausahaan, 2(2):82-87.

Mohri, H. 2013. Assessment of Ecosystem Services in Homegarden System in Indonesia, Sri Lanka, and Vietnam. Ecosystem Services, 5: 124-136.

Purwanto, A.E. 2015. Implementasi Kebijakan Publik, Konsep dan Aplikasinya di Indonesia. Yogyakarta: Gava Media.

Putri, N.P.A., Aini, N dan Heddy, Y.B.S. 2015. Evaluasi Keberlanjutan Kawasan Rumah Pangan Lestari (KRPL) di Desa Girimoyo, Kecamatan Karangploso. Jurnal Produksi Tanaman, 3(4)L 1-4.

Siti, N.R.I dan Sarwadi, A. 2015. Lanskap Pekarangan Produktif di Permukiman Perkotaan dalam Mewujudkan Lingkungan Binaan Berkelanjutan. Prosiding Seminar Nasional Sains dan Teknologi Fakultas Teknik Universitas Muhammadiyah Jakarta: 1-11.

Suharto, E. 2005. Membangun Masyarakat Memberdayakan Rakyat, Kajian Strategi Pembangunan Kesejahteraan Sosial dan Pekerjaan Sosial. Bandung: PT Refika Aditama. 